\title{
Agranulocytosis Developed After Dose Escalation in a Patient Under Chronic Methimazole Treatment
}

\author{
Didem Eroğlu, ${ }^{1}$ Cihangir Çakır, ${ }^{1}$ Ayhan Bekmez,, Berçem Ayçiçek Doğan, ${ }^{2}$ Esma Türkmen ${ }^{3}$
}

$$
\begin{array}{r}
\text { 'Deparment of Internal Medicine, } \\
\text { Derince Training and Research } \\
\text { Hospital, } \\
\text { 2Deparment of Endocrinology, } \\
\text { Derince Training and Research } \\
\text { Hospital, } \\
\text { } \begin{array}{r}
\text { Heparment of Medical Oncology, } \\
\text { Derince Training and Research } \\
\text { Hospital; all Kocaeli, Turkey }
\end{array} \\
\text { Submitted: 02.10.2015 } \\
\text { Accepted: 12.04.2016 } \\
\hline \text { Correspondence: Didem Eroğlu, } \\
\text { Köşklüçeşme Mahallesi, Şehit Halil } \\
\text { Kamış Cad., No: 47/4, Daire: } 12, \\
\text { Gebze, Kocaeli, Turkey }
\end{array}
$$

\section{Dear Editor,}

Agranulocytosis, defined as absolute neutrophil count of less than $500 / \mu \mathrm{L}$, is a life-threatening condition. Many factors, including medications and infection, can cause agranulocytosis. Antithyroid drugs are frequently used in treatment of hyperthyroidism, and agranulocytosis is seen in $0.1 \%$ to $0.5 \%$ of these patients. ${ }^{[1]}$

A 72-year-old female patient presented at outpatient clinic of internal medicine with complaints of fever, lassitude, coughing, and expectoration. Her medical history was unremarkable, except for presence of toxic multinodular goiter and diabetes mellitus. She was taking an oral antidiabetic drug and methimazole. Nearly I week earlier, her daily methimazole dose had been increased from daily dose of $15 \mathrm{mg}$ to $30 \mathrm{mg}$ at another medical center. On her physical examinati- on, skin was hyperemic and moist, heart rate was 95 beats/min, arterial blood pressure was $140 / 90 \mathrm{mmHg}$, and body temperature was $39^{\circ} \mathrm{C}$. Her thyroid gland was palpable, and nodules on thyroid gland could also be palpated. Rales over basal segments of the left lung could be heard. Physical examination of other systems was not remarkable. Biochemical analysis revealed presence of neutropenia (white blood cell count: 300/L, absolute neutrophilia: I0/L). Her C-reactive protein level was high (202 $\mathrm{mg} / \mathrm{L})$. Suppressed thyroid-stimulating hormone level $(0.02 \mathrm{micU} / \mathrm{mL}$; range: $0.57-5.6$ $\mathrm{micU} / \mathrm{mL}$ ) was detected. Free T3 and T4 values, liver and kidney function test results, and serum electrolyte levels were within normal limits. Her peripheral smear result was consistent with neutropenia. Chest X-ray revealed pneumonic infiltrations in left lower lobe of 
the lung. Antibiotherapy was initiated with diagnosis of neutropenic fever, and treatment with granulocyte-colony stimulating factor (G-CSF) was introduced with indication of serious neutropenia. Neither viral tests performed to determine etiology (e.g., hepatitis, cytomegalovirus, Epstein-Barr virus, toxoplasmosis) of agranulocytosis, nor blood and urine cultures revealed any pathology. She was afebrile during follow-up, neutrophil count elevated to normal level on fourth day of treatment, and her clinical condition improved. Since her complaints developed after escalation of methimazole dose, and no explanatory etiology of agranulocytosis was found, neutropenia was thought to be associated with methimazole use. Informed consent was taken from the patient.

In the literature, agranulocytosis related to antithyroid drug use has generally been seen 2 or 3 months after initiating antithyroid drug use. However, there have been cases reported in which condition developed in early period, as early as 6 days of drug use, or in the long-term, I or 2 years after onset of drug therapy. ${ }^{[2,3]}$ Antithyroid drugs easily penetrate bone marrow and typically exert their toxic effect 20-40 days after drug exposure. However, many studies have supported conclusion that development of agranulocytosis is dose dependent. ${ }^{[2-4]}$

Our patient had been using methimazole for 3 years, and agranulocytosis developed after escalation of methimazole dose. Strikingly, neutropenia developed 5 days after dose increase.

When agranulocytosis develops due to methimazole use, drug therapy should be discontinued promptly, the patient should be hospitalized, and appropriate antibiotherapy should be initiated. Some publications have advocated that use of G-CSF increases granulocyte count, while others have demonstrated its ineffectiveness in cases with severe neutropenia. ${ }^{[5-7]}$ Since our patient suffered from severe neutropenia, we used G-CSF therapy, and detected improvement in neutrophil levels after 3 days.

There is potential for development of agranulocytosis after initiation of antithyroid drug therapy, and requirement of emergency treatment in these cases should be kept in mind.

Conflict of interest

None declared.

\section{REFERENCES}

1. Yang J, Zhang J, Xu Q, Sheng GP, Weng WW, Dong MJ. Unusual Synchronous Methimazole-Induced Agranulocytosis and Severe Hepatotoxicity in Patient with Hyperthyroidism: A Case Report and Review of the Literature. Int J Endocrinol 2015;2015:934726.

2. Yang J, Zhong J, Zhou LZ, Hong T, Xiao XH, Wen GB. Sudden onset agranulocytosis and hepatotoxicity after taking methimazole. Intern Med 2012;51:2189-92.

3. Takata K, Kubota S, Fukata S, Kudo T, Nishihara E, Ito M, et al. Methimazole-induced agranulocytosis in patients with Graves' disease is more frequent with an initial dose of $30 \mathrm{mg}$ daily than with 15 mg daily. Thyroid 2009;19:559-63.

4. Cooper DS, Goldminz D, Levin AA, Ladenson PW, Daniels GH, Molitch ME, et al. Agranulocytosis associated with antithyroid drugs. Effects of patient age and drug dose. Ann Intern Med 1983;98:26-9.

5. Dai WX, Zhang JD, Zhan SW, Xu BZ, Jin H, Yao Y, et al. Retrospective analysis of 18 cases of antithyroid drug (ATD)-induced agranulocytosis. Endocr J 2002;49:29-33.

6. Altunbas H, Yazicioglu G, Balci MK, Karayalçin U, Undar L. The use of recombinant human G-CSF in the treatment of propylthiouracilinduced agranulocytosis. Int J Clin Pract 1999;53:396-7.

7. Fukata S, Kuma K, Sugawara M. Granulocyte colony-stimulating factor (G-CSF) does not improve recovery from antithyroid druginduced agranulocytosis: a prospective study. Thyroid 1999;9:29-31. 